\author{
Mariola Tracz \\ Polskie Towarzystwo Geograficzne, Oddział w Krakowie, Polska - Polish Geographical Society, Krakow \\ Branch, Poland
}

Matgorzata Bajgier-Kowalska

Krakowska Akademia im. A.F. Modrzewskiego, Polska - Andrzej Frycz Modrzewski Krakow University, Poland

\title{
Oddziaływanie agroturystyki na rozwój lokalny na przykładzie Karpat
}

\section{Impact of Agritourism on Local Development - Case Study of the Polish Carpathians}

\begin{abstract}
Streszczenie: Karpaty to jeden z ważniejszych regionów turystycznych Polski. Turystyka jest istotnym czynnikiem ich rozwoju oraz źródłem dochodów mieszkańców. Celem opracowania było zdiagnozowanie obszarów oddziaływania agroturystyki na rozwój terenów wiejskich regionu. Do tego celu wykorzystano badania ankietowe oraz studium terenowe. Badania ankietowe przeprowadzono wśród 275 właścicieli kwater agroturystycznych. Wyniki badań wskazują, iż wpływ agroturystyki na rozwój lokalny regionu jest zróżnicowany w stosunku do skali i obszarów oddziaływania. Wyraźnie zaznacza się jedynie w gminach o dużej koncentracji gospodarstw agroturystycznych (ok. 10\% gmin), a w przypadku pozostałych gmin jest on raczej niewielki. Niemniej jednak podmioty agroturystyczne stanowią niejednokrotnie zalążek dla rozwoju przedsiębiorczości w środowisku lokalnym. Respondenci wskazali, iż agroturystyka najczęściej przyczynia się do rozwoju infrastruktury turystycznej (np. rekreacyjno-wypoczynkowej, podniesienia standardu kwater), usług (np. usługi gastronomiczne, handlowe) oraz wspiera rozwój ekonomiczny (np. zatrudnienie, dochody z podatków). Ponadto, działalność agroturystyczna służy podtrzymywaniu i kultywowaniu tradycji wiejskich oraz funkcjonowaniu stowarzyszeń agroturystycznych.
\end{abstract}

\begin{abstract}
The Carpathian Mountains is one of the major tourist destination in Poland. Tourism is an important factor in the socio-economic development and income for residents. The aim of the study was to explain the impact of agritourism on local development of rural areas. Survey study and field study were used. The survey was conducted among 275 owners of agritourism farms. The results showed that the impact of agritourism on the socio-economic development of the region is diverse. It is clearly visible only in communes with a high number of agritourism farms (about $10 \%$ of all communes); in other communes the impact is rather small. Respondents indicated that agritourism most often contributes to an increase in tourist facilities (e.g. recreation and leisure, standard of accommodation), services (e.g. catering, commercial) and effects on local economies (e.g. employment, tax revenues). In addition, agritourism activities contribute to the protection and cultivation of rural traditions and raising civil organisation (e.g. agritourism associations).
\end{abstract}


Słowa kluczowe: agroturystyka; gminy; Karpaty; obszary wiejskie; rozwój lokalny; turystyka

Keywords: agritourism; Carpathian Mountains; communes; local development; rural areas; tourism

Otrzymano: 6 maja 2019

Received: 6 May 2019

Zaakceptowano: 1 sierpnia 2019

Accepted: 1 August 2019

\section{Sugerowana cytacja/Suggested citation:}

Tracz, M., Bajgier-Kowalska, (2019). Oddziaływanie agroturystyki na rozwój lokalny na przykładzie Karpat. Przedsiębiorczość - Edukacja [Entrepreneurship - Education], 15(2), 200-213. doi: $10.24917 / 20833296.152 .14$

\section{Wstęp}

W Polsce wiele małych rodzinnych gospodarstw ma problem $\mathrm{z}$ utrzymaniem dochodowości z powodu rosnących kosztów produkcji i globalizacji rynku rolnego. W tej sytuacji właściciele gospodarstw często podejmują dodatkową działalność lub poszukują zatrudnienia poza rolnictwem. Proces ten występuje przede wszystkim $w$ regionach o niekorzystnych dla rozwoju rolnictwa warunkach przyrodniczych, jakimi są obszary górskie (Musiał, Sroka, Wojewodzic, 2010). Rozwój funkcji turystycznej na terenach wiejskich, w tym szczególnie na obszarach górskich, jest zjawiskiem ważnym, zarówno dla mieszkańców wsi, jak i dla turystów. Turystyka stwarza nowe możliwości użytkowania przestrzeni wiejskiej, zabudowań gospodarczych i lokalnej infrastruktury oraz stanowi zalążek aktywizacji gospodarczej w danej gminie (Dorocki, Szymańska, Zdon-Korzeniowska, 2016; Drzewiecki, 2009; Krysa, Basaj, 2010; Kurek, 2008).

W literaturze przedmiotu termin „rozwój lokalny” jest różnie definiowany. Według części autorów jest on pojmowany $\mathrm{z}$ jednej strony jako tworzenie nowych miejsc pracy na danym terytorium, a z drugiej zaś - jako kompleksowe kształtowanie możliwie najlepszych warunków życia w lokalnym środowisku (Parysek, 1997; Rowe, 2009). W rozwoju lokalnym istotne znaczenie mają: potencjał demograficzny i społeczny, zasoby lokalnego środowiska przyrodniczego oraz poziom instytucjonalny i gospodarczy. Rozwój lokalny dokonuje się na różnych płaszczyznach, szczególnie na płaszczyźnie gospodarczej, politycznej, społecznej i kulturalnej (Zioło, 2016). Współcześnie za ważną strategię rozwoju, szczególnie obszarów wiejskich, jest uznawana turystyka. Umożliwia ona bowiem gospodarstwom rolnym pozyskiwanie dodatkowych dochodów, sprzyja tworzeniu nowych powiązań między gospodarstwami oraz większemu powiązaniu ich z rynkiem (Kizos, 2010).

Turystyka wiejska najczęściej jest definiowana jako rodzaj usług turystycznych obejmujących zakwaterowanie, wyżywienie i rekreację na obszarach wiejskich (Roman, Niedziółka, 2017). Jej różne formy, w tym agroturystyka, są szansą aktywizacji i ożywienia gospodarczego wsi. Wpisuje się ona w model wielofunkcyjnego rozwoju obszarów wiejskich - daje szansę na rozwój gospodarstw, a jednocześnie pełni funkcje rekreacyjne i edukacyjne (Sznajder, Przezbórska, 2006; Tew, Barbieri, 2012). Agroturystyka jako forma turystyki wiejskiej związana jest $\mathrm{z}$ organizowaniem wypoczynku na terenach wiejskich na podstawie noclegu i aktywności rekreacyjnych w gospodarstwie rolnym (Bajgier-Kowalska, Tracz, Uliszak, 2016; Drzewiecki, 2009; Gralak, Kacprzak, 2018; Sznajder, Przezbórska, 2006; Wojciechowska 2009). Obecnie pojęcie to ma znaczenie szersze i obejmuje różne 
rodzaje działalności związane z obsługą nie tylko turystów, lecz także wczasowiczów (Arroyo i in., 2013; Phillip, Hunter, Blackstock, 2010; Zawadka, 2010). Agroturystyka stała się stałym elementem krajobrazu polskiej wsi. Najwięcej kwater agroturystycznych znajduje się w najatrakcyjniejszych pod względem turystycznym regionach, tj. w górach (zwłaszcza w Karpatach), nad morzem oraz na pojezierzach (zwłaszcza na Pojezierzu Warmińsko-Mazurskim). Poza tymi regionami tylko nieliczne gminy dysponują bazą noclegową, która pozwala widzieć w turystyce wiejskiej, w tym w agroturystyce, szansę stymulowania rozwoju lokalnego (Bednarek-Szczepańska, Bański, 2014; Dorocki, Szymańska, Zdon-Korzeniowska, 2016; Przezbórska-Skobiej, Sobotka, 2016).

Celem niniejszego opracowania jest poznanie wpływu agroturystyki na rozwój lokalny na przykładzie polskich Karpatach. Gospodarstwa agroturystyczne stanowią w regionie istotny element lokalnej bazy turystycznej i indywidualnej przedsiębiorczości.

\section{Przegląd literatury}

Rola agroturystyki w rozwoju obszarów wiejskich, w tym i w produkcji rolniczej, jest zagadnieniem wieloaspektowym. W polityce rolnej Unii Europejskiej agroturystyka traktowana jest jako jeden $\mathrm{z}$ istotnych składników strategii rozwoju lokalnego oraz programów aktywizacji ekonomicznej i restrukturyzacji obszarów wiejskich (PROW 2014-2020). Do głównych beneficjentów rozwoju agroturystyki zaliczani są turyści, właściciele kwater agroturystycznych, społeczności lokalne oraz instytucje/władze lokalne odpowiedzialne za rozwój społeczno-gospodarczy regionu. Niektóre badania potwierdzają teoretyczne założenie, iż agroturystyka na obszarach wiejskich przyczynia się do podtrzymywania zatrudnienia rolników, wpływa na uruchamianie nowych podmiotów gospodarczych związanych z obsługą turystów oraz zagospodarowaniem produktów rolnych (Mysiak, 2000; Rogerson, Rogerson, 2014; Flanigan, Blackstock, Hunter, 2015; Dorocki, Szymańska, Zdon-Korzeniowska, 2016; Pałka-Łebek, 2017).

W wielu opracowaniach podkreślany jest wpływ agroturystyki na aktywizację ekonomiczną obszarów wiejskich. Jednym z najczęściej podawanych motywów podejmowania działalności agroturystycznej jest możliwość uzyskania dodatkowego dochodu (Bagi, Reeder, 2012; Dorocki, Szymańska, Zdon-Korzeniowska, 2016; Komorowska, 2003; McGehee, Kim, 2004). Rozwój agroturystyki w regionach atrakcyjnych turystycznie jest ważnym czynnikiem wspierającym rozwój usług, np. gastronomi i rzemiosła, które dają zatrudnienie mieszkańcom wsi (Koutsouris i in., 2014; Karampela, Kizos, Spilanis, 2016). Gospodarstwa agroturystyczne mogą pozyskiwać dodatkowy dochodu, oprócz opłaty za nocleg, z rozbudowanej oferty turystycznej, m.in.: opłaty za wyżywienie, wypożyczanie sprzętu sportowego, sprzedaży nadwyżek produktów rolnych, pamiątek itp. (Balińska, Zawadka, 2013; Brown, Reeder, 2007). Uzyskane fundusze zasilają budżety lokalne w postaci bezpośredniej - podatków - lub pośredniej, objawiającej się zwiększoną konsumpcją dóbr i usług. Równocześnie wzrost dostępu do niektórych usług i modernizacja infrastruktury przyczyniają się do podwyższenia jakości życia na obszarach wiejskich (Cichowska, Klimek, 2011). W regionach o dużym natężeniu ruchu turystycznego z czasem wielu gestorów agroturystycznych przechodzi na typowe usługi związane z turystyką wiejską. Turystyka staje się więc podstawowym źródłem utrzymania znacznej części mieszkańców. W Polsce przykładem są regiony nadmorskie oraz górskie (Dorocki, Szymańska, Zdon-Korzeniowska, 2016; Bajgier-Kowalska, Tracz, Uliszak, 2017; Tracz, 
Bajgier-Kowalska, Uliszak, 2017). Agroturystyka staje się jednym z elementów wspierających zrównoważony rozwój terytorialny, m.in. przez wspieranie produktywności na obszarach wiejskich, zwiększanie zatrudnienia, partycypację w podziale dochodów oraz tworzenie się sieci powiązań między gospodarstwami rolnymi, agroturystycznymi i ekologicznymi (Marin, 2015; Pałka-Łebek, 2017).

Niektórzy badacze wskazują na oddziaływanie agroturystyki na zachowanie krajobrazu i dziedzictwa wiejskiego (Cichowska, Klimek, 2011). Jednym z istotnych czynników rozwoju agroturystyki $\mathrm{w}$ danym regionie jest przede wszystkim atrakcyjne środowisko przyrodnicze. Wiele studiów potwierdza, iż duże nagromadzenie kwater agroturystycznych występuje w sąsiedztwie parków narodowych i krajobrazowych oraz obiektów historycznych i architektonicznych znajdujących się na obszarach wiejskich (WoĨniak, KuĨniar, 2000; Płazińska, 2016; Przezbórska-Skobiej, Sobotka, 2016). Właściciele kwater agroturystycznych są zainteresowani działaniami władz lokalnych na rzecz ochrony dziedzictwa przyrodniczego i kulturowego, gdyż przekładają się one na liczbę gości, a tym samym - na dochody osiągane $z$ agroturystyki.

Rozwój agroturystyki może wpływać na przemiany zachodzące w produkcji rolniczej w skali lokalnej. Im intensywniej rozwija się agroturystyka w danym regionie, tym większe zapotrzebowanie na produkty rolnicze (np. drób, jajka, ryby, owoce, mleko). Gospodarstwa agroturystyczne mogą stymulować rozwój niektórych dziedzin rolnictwa, m.in. ogrodnictwo, pszczelarstwo, hodowlę bydła mlecznego, owiec (Karampela, Kizos, Spilanis, 2016; Koutsouris i in., 2014). Usługodawcy agroturystyczni współpracują ze sobą w różnych obszarach. W Polsce najczęstszym przedmiotem działania jest wymiana gości, doświadczeń i informacji oraz działania w zakresie wspólnej promocji (Cichowska, Klimek, 2011). Natomiast oddziaływanie agroturystyki na podtrzymywanie produkcji rolniczej jest raczej niewielkie, gdyż jak wynika z badań, agroturystykę podejmują głównie gospodarstwa $\mathrm{z}$ zanikającym lub marginalnym rolnictwem (Bednarek-Szczepańska, 2011; Sikora, 2014; Dorocki, Szymańska, Zdon-Korzeniowska, 2016; Tracz, Bajgier-Kowalska, Uliszak, 2018). Warto zaznaczyć, że agroturystyka w sposób szczególny sprzyja edukacji ekologicznej społeczeństwa, w tym dzieci i młodzieży. Przebywanie na terenach wiejskich, w gospodarstwie edukacyjnym, pozwala lepiej zrozumieć takie zagadnienia, jak rolnictwo ekologiczne, gospodarowanie w harmonii z przyrodą itp. (Balińska, Zawadka, 2013; Roman, Niedziółka, 2017). Agroturystyka pobudza również rozwój społeczny na wsi, w tym rozwój inicjatyw (np. usługi transportowe i przewodnickie), zwiększa dbałość społeczności lokalnej o wygląd wsi oraz działania instytucji i stowarzyszeń lokalnych o podtrzymywanie lokalnej tradycji, kultury oraz rękodzielnictwa (Balińska, Zawadka, 2013; Cichowska, Klimek, 2011; Dorocki, Szymańska, Zdon-Korzeniowska, 2016; Dubois, Cawley, Schmitz, 2017).

Agroturystyka może również wywoływać negatywne skutki na obszarach wiejskich. Jednym z nich, jak potwierdzają badania, jest wyłączanie gruntów z produkcji rolniczej na cele rekreacyjne i wypoczynkowe (place zabaw, wyciągi narciarskie itp.) oraz wzrost nieużytków rolnych (Klima, 2015). Równocześnie pod wpływem rozwoju turystyki, w tym agroturystyki, następują: zmiana użytkowania i struktury własności ziemi, wzrost osadnictwa letniskowego i infrastruktury turystycznej (Fleischer, Tchetchik, 2005; Roman, Niedziółka, 2017; Dorocki, Kroczak, Bryndal, 2019), a także odchodzenie od agroturystyki w kierunku typowej turystyki wiejskiej (Bajgier-Kowalska, Tracz, Uliszak, 2017). 
Wpływ agroturystyki na lokalną gospodarkę uzależniony jest od skali działania i sieci powiązań wytworzonych z innymi lokalnymi przedsiębiorstwami. Możliwych jest wiele różnych oddziaływań, które prowadzą do różnych zmian. Jedynie studia empiryczne dla poszczególnych gmin lub większych regionów mogą uchwycić skalę tego oddziaływania. Przykładem są studia Karampeli i innych (2016) nad koncepcyjnymi ramami badań nad oddziaływaniem agroturystyki na rozwój lokalny małych wysp. Model ten uwzględnia rożne rodzaje agroturystyki oraz skalę i sieci powiązań między przedsiębiorstwami. Niniejsze opracowanie wypełnia lukę dotyczącą poznania stanu i poziomu oddziaływania agroturystyki na rozwój lokalny na przykładzie polskiej części Karpat.

\section{Obszar i metodyka badań}

Do badań wybrano obszar polskich Karpat, na którym w ostatnich dekadach turystyka, w tym turystyka wiejska, rozwijała się intensywnie. Region ten obejmuje 215 gmin położonych w 3 województwach: podkarpackim, małopolskim i śląskim.

O atrakcyjności turystycznej Karpat świadczą m.in.: zróżnicowany krajobraz, znaczny udział obszarów leśnych (40\% ogólnej powierzchni), bogactwo parków narodowych (6), parków krajobrazowych (13) i obszarów chronionego krajobrazu (10). Bogate są również: dziedzictwo kulturowe, folklor i sztuka ludowa, a wybrane drewniane obiekty sakralne wpisano na Listę UNESCO. Istniejące zasoby przyrodniczo-kulturowe oraz infrastruktura turystyczno-rekreacyjna sprzyjają rozwojowi różnych form turystyki. Karpaty, pomimo podobieństwa przyrodniczego i społeczno-kulturowego, są regionem wewnętrznie zróżnicowanym, szczególnie pod względem gęstości zaludnienia, poziomu zatrudnienia w rolnictwie, zagospodarowania turystycznego i ruchu turystycznego (Bajgier-Kowalska, Tracz, 2019; Kurek, 2008).

Tradycyjna agroturystyka, łącząc funkcję rolniczą i turystyczną, jest ważną formą turystyki z punktu widzenia zrównoważonego rozwoju. Według danych z ODR-ów, w $2018 \mathrm{r}$. na obszarze polskiej części Karpat były 893 kwatery agroturystyczne. Jednak faktyczna ich liczba jest trudna do oszacowania. Wynika to $\mathrm{z}$ faktu nierejestrowania części gospodarstw agroturystycznych $\mathrm{z}$ powodu przyjętych regulacji prawnych (gospodarstwo oferujące do 5 pokoi nie musi rejestrować działalności) oraz dowolnego rozumienia terminu „agroturystyka”. Według danych GUS-u, w 2006 r. w Karpatach było ponad 2000 gospodarstw agroturystycznych z 22000 miejsc noclegowych. Aktualnie część badaczy szacuje, że liczba gospodarstw agroturystycznych nie przekracza 1500 obiektów (Bajgier-Kowalska, Tracz, Uliszak, 2016; Dorocki, Szymańska, Zdon-Korzeniowska, 2016; Przezbórska-Skobiej, Sobotka, 2016). Oferta agroturystyczna dostępna jest w większości gmin karpackich (72\%), ale $\mathrm{w}$ połowie $\mathrm{z}$ nich liczba gospodarstw agroturystycznych nie przekracza pięciu. Najwięcej kwater agroturystycznych znajduje się w kilku gminach położonych w otoczeniu Tatr, w Beskidzie Sądeckim, Śląskim i Niskim oraz w Bieszczadach, a znacznie mniej na pogórzach (Bajgier-Kowalska, Tracz, 2019).

Celem niniejszego badania było poznanie wpływu działalności agroturystycznej na rozwój lokalny gmin karpackich. Szczegółowe badania dotyczyły poznania korzyści, jakie płyną z oddziaływania agroturystyki dla mieszkańców (indywidualnie/społeczności) oraz na wiejskie otoczenie i rozwój turystyki w regionie. Do realizacji założonych celów posłużono się badaniami ankietowymi oraz studiami terenowymi. Wykorzystano także dane statystyczne pozyskane z GUS-u i regionalnych ODR-ów. 
Do badań kwestionariuszowych wybrano losowo po 200 gospodarstw agroturystycznych z obszaru województwa małopolskiego i podkarpackiego oraz 50 gospodarstw z województwa śląskiego. Badania ankietowe przeprowadzono za pomocą kwestionariusza wysyłanego drogą mailową w 2018 r. (od marca do września). Wykorzystano w tym celu bazę kwater agroturystycznych dostępną na stronach małopolskiego i podkarpackiego ODR-u oraz portali internetowych powiatów/gmin karpackich. Otrzymano zwrot łącznie 275 wypełnionych ankiet. W ankietowanej grupie kobiety stanowiły 62,0\%. Dominowały osoby w wieku 35-60 lat (74,0\%), a większość badanych miała wykształcenie średnie (75,0\%). Działalność agroturystyczna była rejestrowana przez kobiety $(55,5 \%)$ oraz jako działalność rodzinna (25,7\%). Ankietowane gospodarstwa agroturystyczne funkcjonowały na rynku średnio od 5 do 15 lat (49,2\%). Kwestionariusz ankiety zawierał m.in. pytania dotyczące: powierzchni gospodarstwa, liczby zatrudnionych w agroturystyce, inwestycji (adaptacyjnych, technicznych, rekreacyjnych, transportowych, edukacyjnych itp.) podejmowanych w gospodarstwie oraz w miejscowościach związanych z usługami turystycznymi, współpracy z innymi podmiotami oraz stowarzyszeniami agroturystycznymi, oferty agroturystycznej. Badania ankietowe uzupełniono studium terenowym (wrzesień - październik) w kilku gminach (Beskidy i Pogórze Karpackie) oraz wywiadami z przedstawicielami władz lokalnych i stowarzyszeń agroturystycznych.

\section{Wyniki badań i dyskusja}

Odpowiedzi respondentów na pytanie ogólne o wpływ agroturystyki na rozwój lokalny były różnorodne, ale najwięcej wskazań dotyczyło rozwoju turystyki, przedsiębiorczości oraz podnoszenia jakości życia i ochrony przyrody w miejscowości (tabela 1).

Tabela 1. Możliwości oddziaływania agroturystyki na rozwój lokalny w ocenie badanych

\begin{tabular}{|l|c|c|c|c|c|}
\hline \multirow{2}{*}{\multicolumn{1}{c|}{ Wyszczególnienie }} & \multicolumn{5}{c|}{ Liczba wskazań } \\
\cline { 2 - 6 } & Tak & Raczej tak & $\begin{array}{c}\text { Trudno } \\
\text { powiedzieć }\end{array}$ & Raczej nie & Nie \\
\hline Rozwój przedsiębiorczości & 46 & 89 & 73 & 42 & 25 \\
\hline Rozwój rolnictwa & 11 & 72 & 53 & 101 & 38 \\
\hline Zatrudnienie & 24 & 73 & 76 & 84 & 18 \\
\hline $\begin{array}{l}\text { Podnoszenie jakości życia } \\
\text { w miejscowości }\end{array}$ & 24 & 88 & 63 & 87 & 13 \\
\hline Ochrona przyrody & 29 & 92 & 78 & 45 & 31 \\
\hline $\begin{array}{l}\text { Rozwój turystyki } \\
\text { w miejscowości }\end{array}$ & 60 & 124 & 69 & 14 & 8 \\
\hline
\end{tabular}

Źródło: opracowanie własne

Na podstawie szczegółowych pytań ankietowych wyodrębniono grupy czynników, które w opinii usługodawców agroturystycznych są istotne z punktu widzenia oddziaływania agroturystyki na rozwój lokalny (tabela 2). W ocenie badanych działalność agroturystyczna przynosi korzyści zarówno ekonomiczne, jak i społeczne oraz kulturowe. Wydaje się, że mieszkańcy postrzegają wpływ agroturystyki jako nową szansę dla działalności pozarolniczej. Na ten aspekt wskazują wysokie rangi przypisywane takim czynnikom, jak dbanie o estetykę ogródków przydomowych, budowa obiektów rekreacyjnych oraz zatrudnienie. 
Właściciele kwater agroturystycznych podejmują inwestycje związane z adaptacją budynków dla potrzeb turystów (nowe pokoje, łazienki, jadalnie), a także wzbogacają dostępną infrastrukturę rekreacyjną (np. place zabaw, miejsca na ogniska, boiska sportowe).

Rozwój turystyki i agroturystyki w miejscowości pociąga za sobą modernizację lub budowę dróg, wodociągów i kanalizacji oraz wzrost dostępności do internetu. Jest to wymuszone presją spowodowaną wzrostem ruchu turystycznego, a z drugiej strony - zwiększonym wpływem środków do budżetu gmin z tytułu wzrostu zatrudnienia i liczby podmiotów obsługujących turystów (tabela 2). Działania w zakresie rozbudowy infrastrukturalnej były i są wspierane przez samorządy lokalne w ramach programów pozarolniczej aktywizacji wsi. Ważną rolę odegrały w tym programy strukturalne, np. „Restrukturyzacja i modernizacja sektora żywnościowego i rozwój obszarów wiejskich” (2004-2006), który wspierał m.in. projekty przyczyniające się do rozwoju infrastruktury związanej z rozwojem funkcji turystycznych wsi (Sektorowy..., 2006).

Tabela 2. Oddziaływanie agroturystyki na rozwój lokalny w opinii badanych (respondenci mogli wskazać więcej niż jedną odpowiedź)

\begin{tabular}{|l|c|c|c|}
\hline \multicolumn{1}{|c|}{ Wyszczególnienie } & $\begin{array}{c}\text { Liczba } \\
\text { wskazań }\end{array}$ & $\%$ & Ranga \\
\hline 1. Rozwój usług: & 118 & 43 & 3 \\
- więcej sklepów & 179 & 65 & 1 \\
- nowe obiekty gastronomiczne (np. bary, restauracje, zajazdy) & & 52 & 2 \\
- więcej obiektów noclegowych & 143 & 52 & \\
- wypożyczalnie sprzętu sportowego (rowerów, nart, łódek itp.) & & & \\
\hline 2. Rozwój infrastruktury drogowej i turystycznej: & 113 & 41 & 4 \\
- rozbudowa sieci wodociągowej i kanalizacyjnej & 187 & 68 & 3 \\
- budowa dróg, chodników, przejść dla pieszych & 192 & 70 & 2 \\
- budowa obiektów rekreacyjnych (boisk sportowych, parków & & & \\
linowych, basenów termalnych, placów zabaw dla dzieci, & 52 & 19 & 7 \\
$\quad$ tworzenie parków, skwerów) & 60 & 22 & 6 \\
- nowe szlaki turystyczne & 66 & 24 & 5 \\
- adaptacja zabudowań gospodarczych dla potrzeb gości & 225 & 82 & 1 \\
- rozbudowa gospodarstwa agroturystycznego & & & \\
- dbanie o estetykę ogródków przydomowych & 113 & 41 & 2 \\
\hline 3. Rozwój ekonomiczny: & 149 & 54 & 1 \\
- dochody z podatków & 91 & 33 & 3 \\
- miejsca pracy przy obsłudze gości & & & \\
- sprzedaż produktów z gospodarstwa & 187 & 68 & 1 \\
\hline 4. Rozwój społeczny: & 96 & 35 & 3 \\
- podnoszenie kwalifikacji (kursy, szkolenia) & 60 & 22 & 4 \\
- stowarzyszenia usługodawców agroturystycznych & 115 & 42 & 2 \\
- aktywizacja miejscowej administracji & 160 & 58 & 1 \\
- więcej turystów & 66 & 24 & 2 \\
\hline 5. Rozwój kulturalny: & 50 & 18 & 3 \\
- kultywowanie tradycji wiejskich (zespoły ludowe, koła gospodyń & & 15 & 4 \\
- wiejskich itp.) & & \\
- promowanie kuchni regionalnej i produktów zdrowej żywności & & \\
(kiermasze, targi, degustacje) kultywowanie pasterstwa & & \\
- imprezy kulturalne & & \\
\hline
\end{tabular}

Źródło: opracowanie własne 
Drugim obszarem istotnego oddziaływania agroturystyki według badanych był rozwój usług na wsi. Zaliczono tutaj większą dostępność typowych usług handlowych - sklepów (np. nowe lokalne centra handlowe), jak także obiektów służących wyłącznie turystom, np. punktów informacji turystycznej, obiektów zakwaterowania oraz punktów gastronomicznych (bary, karczmy, kawiarnie). Należy zaznaczyć, iż poprawa i rozbudowa lokalnej infrastruktury technicznej i rekreacyjnej, większa dostępność do niektórych usług, podnosi atrakcyjność miejscowości oraz poprawia standard życia mieszkańcom wsi.

W obszarze oddziaływania społecznego badani gestorzy agroturystyczni wskazali na kilka aspektów. Do ważniejszych zaliczyli przede wszystkim aktywizację zawodową, w tym zatrudnienie kobiet w obsłudze gości w gospodarstwie i w innych usługach towarzyszących (bary, restauracje). Na znaczenie agroturystyki w dywersyfikacji zatrudnienia na wsi wskazują także badania prowadzone m.in. w Serbii, Chorwacji i na Tajwanie, choć skala tego zjawiska jest zróżnicowana regionalnie (Stanovčić i in., 2018; Wang, Pfister, 2008; Petrović i in., 2016). Badani wskazali także na ważne kompetencje indywidualne, takie jak: podnoszenie poziomu wiedzy i umiejętności (np. z zakresu zarządzania i tworzenia produktu agroturystycznego), kształcenie umiejętności kontaktu z klientem oraz aplikowania o fundusze na rozwój działalności agroturystycznej. Zdaniem ankietowanych, agroturystyka w polskich Karpatach przyczynia się również do kultywowania pasterstwa i wytwarzania produktów żywnościowych (np. sery owcze i kozie). Podtrzymywaniu tego typu gospodarki służą uruchamiane ze środków unijnych programy dla podtrzymania tradycji i kultury pasterskiej w Karpatach. Jest to szczególnie widoczne na Podhalu, w Beskidzie Niskim i w Bieszczadach.

W opinii władz lokalnych turystyka i agroturystyka wpływa na wzrost podmiotów świadczących usługi pozarolnicze, w tym głównie handlowe, gastronomiczne i transportowe, co przekłada się na wzrost dochodów gminy. Respondenci wskazali, iż agroturystyka była jednym z elementów ograniczających skalę bezrobocia na wsi, szczególnie $\mathrm{w}$ okresie transformacji ustrojowej. Inwestycja w agroturystykę zapewniała rolnikom pracę i dodatkowe źródło dochodów. W obsłudze gości pracują głównie członkowie rodziny. Jedynie w sezonie letnim w miejscowościach typowo turystycznych zatrudniane są dodatkowe osoby (tabela 3 ).

Tabela 3. Oddziaływanie agroturystyki na zatrudnienie w opinii badanych

\begin{tabular}{|c|c|c|}
\hline \multirow{2}{*}{$\begin{array}{c}\text { Liczba pracujących } \\
\text { w gospodarstwie } \\
\text { agroturystycznym } \\
\text { [osoby] }\end{array}$} & \multicolumn{2}{|c|}{ \% gospodarstw agroturystycznych } \\
\cline { 2 - 3 } & stałe zatrudnienie & $\begin{array}{c}\text { dodatkowe } \\
\text { zatrudnienie } \\
\text { w sezonie }\end{array}$ \\
\hline 1 & 76,5 & 30,2 \\
\hline 2 & 21,0 & 25,7 \\
\hline 3 & 2,5 & 0,0 \\
\hline 4 i więcej & 0,0 & 0,0 \\
\hline
\end{tabular}

Źródło: opracowanie własne

Ponadto przedstawiciele stowarzyszeń agroturystycznych i władz lokalnych wskazali na wzrost inicjatyw podtrzymujących kulturę lokalną (zespoły ludowe, koła gospodyń wiejskich), wzbogacanie oferty turystycznej (imprezy kulturalne, kuchnia regionalna), wzrost popytu na lokalne produkty rolne, co prowadzi do podtrzymania działalności 
rolniczej i więzi społecznych, oraz na edukacyjne znaczenie gospodarstw dla odwiedzających. W celu zwiększenia oferty rekreacyjnej wytyczane są nowe szlaki turystyczne, stawiane są tablice informacyjne oraz tworzone są strony internetowe promujące walory turystyczne miejscowości.

Analiza danych statystycznych oraz wywiady z przedstawicielami władz lokalnych i organizacji agroturystycznych wykazały zmniejszające się zainteresowanie działalnością agroturystyczną w regionie (tabela 4). Fakt ten nie pozostaje bez wpływu na siłę oddziaływania agroturystyki na rozwój lokalny.

Tabela 4. Liczba gospodarstw agroturystycznych w wybranych gminach w Karpatach

\begin{tabular}{|l|r|c|c|}
\hline \multicolumn{1}{|c|}{ Powiat/Gminy } & $\mathbf{2 0 0 7}$ & $\mathbf{2 0 1 4}$ & $\mathbf{2 0 1 8}$ \\
\hline bieszczadzki & 85 & 70 & 68 \\
Ustrzyki Dolne & 46 & 43 & 13 \\
Lutowiska & 23 & 12 & 13 \\
\hline brzozowski & 22 & 21 & 19 \\
Dydnia & 6 & 7 & 7 \\
Nozdrzec & 8 & 5 & 4 \\
\hline limanowski & 169 & 63 & 60 \\
Niedźwiedź & 24 & 20 & 15 \\
Mszana Dolna & 17 & 11 & 11 \\
\hline nowosądecki & 250 & - & 48 \\
Gródek n/Dunajcem & 27 & 19 & 14 \\
Muszyna & 32 & 23 & 12 \\
\hline nowotarski & 340 & - & 50 \\
Czorsztyn & 165 & 60 & 24 \\
Łapsze Niżne & 29 & 19 & 10 \\
\hline tatrzański & 370 & - & 54 \\
Bukowina Tatrzańska & 160 & 31 & 31 \\
Biały Dunajec & 88 & 37 & 37 \\
\hline
\end{tabular}

Źródło: opracowano na podstawie danych z ODR-ów

Przykładem mogą być gminy na Podhalu i w Bieszczadach, gdzie pomimo spadku liczby kwater agroturystycznych ich koncentracja jest nadal znaczna. W gminie Łapsze Niżne (powiat nowotarski) jest 10 gospodarstw agroturystycznych, a także wiele kwater turystycznych (80), pensjonatów (5) i domów wczasowych (4). Miejscowa ludność obecnie głównie związana jest z działalnością pozarolniczą, w tym obsługą ruchu turystycznego. Turystom i wczasowiczom oferowane są różne formy spędzania wolnego czasu (np. jazda konna, narciarstwo, wędkarstwo, żeglarstwo). Powstały nowe punkty gastronomiczne oraz sklepy. Gmina stale rozbudowuje infrastrukturę turystyczno-rekreacyjną. Wybudowano kilka siłowni na wolnym powietrzu (9), wytyczono piesze i rowerowe ścieżki ukazujące walory krajobrazowo-przyrodnicze gminy i jej okolic. Rozbudowywany jest szlak rowerowy „Pętla Spiska”, a w planie są m.in. budowa ścieżki rowerowej wokół J. Czorsztyńskiego oraz nowych, wielofunkcyjnych boisk sportowych (5). Gmina ta jest przykładem silnego oddziaływania turystyki, w tym agroturystyki, na rozwój przestrzenny, gospodarczy i społeczny miejscowości. Między różnymi podmiotami turystyki wiejskiej wytworzyły się sieci powiązań. Kwatery agroturystyczne stanowią uzupełnienie lokalnej bazy noclegowej. 
Inaczej przedstawia się sytuacja na Pogórzu Karpackim, gdzie w większości gmin liczba gospodarstw agroturystycznych nie przekracza 5 obiektów. W gminie Dydnia (pow. brzozowski) jest 7 kwater agroturystycznych (w 2007 r. było ich 8) oraz 8 pól biwakowych. Ludność gminy głównie związana jest z działalnością rolniczą, a turystyka jest działalnością dodatkową. Wytyczono tu kilka szlaków pieszych, rowerowych i samochodowych służących poznaniu walorów przyrodniczych i kulturowych gminy (np. szlak drewnianych świątyń, szlak dworów). Turystom i wczasowiczom oferowane są typowe formy spędzania wolnego czasu, związane $\mathrm{z}$ walorami lokalnego środowiska (np. spacery, nordic walking, grzybobranie, wędkowanie). Dostępne są również obiekty sportowe, głównie boiska sportowe przy szkołach. Atrakcją turystyczną są spływy kajakowe przełomami Sanu. Przytoczone przykłady uwidaczniają różnicę skali oddziaływania agroturystyki na rozwój obszarów wiejskich, w tym szczególnie infrastruktury turystycznej i rekreacyjnej.

\section{Podsumowanie}

Rozwój agroturystyki, podobnie jak innych form turystyki, w różnym stopniu wpływa na lokalną społeczność. Wyniki badań wskazują, że agroturystyka w Karpatach przyczynia się przede wszystkim do rozbudowy infrastruktury turystycznej, drogowej i rekreacyjnej oraz wzrostu dostępności do usług na wsi. Ważne dla ankietowanych były działania związane z modernizacją gospodarstwa, w tym większa dbałość o estetykę domów i otoczenia. W sytuacji, gdy rolnictwo traci na znaczeniu w Karpatach, mieszkańcy postrzegają agroturystykę jako szansę na zatrudnienie i uzyskiwanie dochodów, podnoszenie kwalifikacji zawodowych, a także jako nowe wyzwanie społeczne i kulturowe. $\mathrm{Z}$ wielu pozytywnych skutków kojarzonych $\mathrm{z}$ wpływem agroturystyki na obszary wiejskie w regionie na szczególne podkreślenie zasługuje jej pozytywne oddziaływanie na rozwój turystyki, lokalnej przedsiębiorczości i rozbudowy infrastruktury. W ten sposób agroturystyka przyczynia się do podnoszenia jakości przestrzeni wiejskiej.

Potwierdza się, że oddziaływanie agroturystyki na lokalną gospodarkę uzależnione jest od liczby tych obiektów i sieci wytworzonych przez nie powiązań z innymi lokalnymi podmiotami gospodarczymi. W Karpatach największa koncentracja gospodarstw agroturystycznych występuje w kilkunastu gminach (10\% gmin karpackich) głównie położonych w obszarach o wybitnych walorach przyrodniczych i rozbudowanej infrastrukturze turystycznej (np. Podhale, Beskidy Wschodnie). Agroturystyka pełni w tych gminach alternatywną funkcję gospodarczą i społeczną. W przypadku gmin o znacznie mniejszym natężeniu aktywności agroturystycznej dotyczy to szczególnie gmin na Pogórzu Karpackim, oddziaływanie tego typu działalności realizuje inne funkcje społeczne. Agroturystyka umożliwia tu harmonijne włączenie się gospodarstw w życie gospodarcze i społeczne lokalnej społeczności. Działalność agroturystyczna była i jest tu niejednokrotnie pionierską inicjatywą przedsiębiorczą, oferującą miejsca noclegowe i wypoczynkowe. W ten sposób przyczynia się do wzrostu dostępności turystycznej regionu i poprawy wizerunku tych miejscowości.

Warto zaznaczyć, że w gminach o dużej atrakcyjności turystycznej i jednocześnie dużej koncentracji kwater agroturystycznych, wyraźnie zaznacza się wypieranie rolnictwa oraz utrata walorów wiejskości na rzecz rozwoju turystyki na obszarach wiejskich i związanego $\mathrm{z}$ tym rozwoju infrastruktury (np. wyciągi narciarskie, pensjonaty). Kwatery agroturystyczne stanowią tu jedynie bazę noclegową do uprawiania różnych form turystyki. 
W przyszłości obszary te mogą być mało atrakcyjne dla zainteresowanych autentyczną agroturystyką. W tej sytuacji wyzwaniem dla gestorów agroturystycznych i władz lokalnych staje się dostosowanie oferty agroturystycznej do potrzeb współczesnego turysty nastawionego na konsumpcję dóbr oferowanych przez tereny wiejskie i tradycyjną wieś. W ofercie gospodarstw, obok zakwaterowania, winny być rozbudowywane inne elementy wykorzystujące zasoby, zarówno gospodarstwa, jak i otoczenia (dziedzictwo przyrodnicze i kulturowe, lokalną żywność, atrakcje turystyczne). Jest to jedna z dróg do większej integracji gospodarstw agroturystycznych $\mathrm{z}$ innymi podmiotami lokalnej gospodarki.

\section{Literatura}

References

Arroyo, C.G., Barbieri, C., Rich, S.R. (2013). Defining agritourism: Acomparative study of stakeholders' perceptions in Missouri and North Carolina. Tourism Management, 37, 39-47.

Bagi, F.S., Reeder, R. (2012). Factors affecting farmer participation in agritourism. Agricultural and Resource Economics Review, 41(2), 189-199.

Balińska, A., Zawadka, J. (2013). Znaczenie agroturystyki w rozwoju obszarów wiejskich. Zeszyty Naukowe SGGW w Warszawie. Ekonomika i Organizacja Gospodarki Żywnościowej, 102, 127-143.

Bajgier-Kowalska, M., Tracz, M. (2019). Bariery rozwoju przedsiębiorczości na przykładzie agroturystyki w polskich Karpatach. Przedsiębiorczość - Edukacja, 15(1), 158-172.

Bajgier-Kowalska, M., Tracz, M., Uliszak, R. (2017). Modeling the state of agritourism in the Malopolska region of Poland. Tourism Geographies, 19(3), 502-524.

Bajgier-Kowalska, M., Tracz, M., Uliszak, R. (2016). Uwarunkowania rozwoju przedsiębiorczości na obszarach wiejskich na przykładzie gospodarstw agroturystycznych województwa małopolskiego. Przedsiębiorczość - Edukacja, 12, 256-273.

Bednarek-Szczepańska, M. (2011). Agritourism in Poland - self government's view versus reality. Discussion Papers 2011. Special Issue - Aspects of Localities. Pozyskano z: http://discussionpapers. rkk.hu/index.php/DP/article/view/2473

Bednarek-Szczepańska, M., Bański, J. (2014). Lokalizacyjne uwarunkowania rozwoju gospodarstw agroturystycznych w Polsce. Przegląd Geograficzny, 96(2), 243-260.

Brown, D., Reeder, R. (2007). Farm-Based Recreation: A Statistical Profile. Economic Research Service. Economic Research Report, 53. Pozyskano z: https://www.ers.usda.gov/webdocs/publications/45941/12871_err53.pdf? $v=0$

Cichowska, J., Klimek, A. (2011). The role of agrotourism in the development and conversion of rural areas. Infrastruktura i Ekologia Terenów Wiejskich, 11, 97-107.

Drzewiecki, M. (2009). Agroturystyka współczesna w Polsce. Gdańsk: Wyższa Szkoła Turystyki i Hotelarstwa w Gdańsku.

Dubois, C., Cawley, M., Schmitz, S. (2017). The tourist on the farm: A 'muddled' image. Tourism Management, 59, 298-311.

Dorocki, S., Szymańska, A. I., Zdon-Korzeniowska, M. (2016). Agricultural tourism farms in Poland: How the farmers improve their businesses - a case study. In: G. Micek (red.), Understanding Innovation in Emerging Economic Spaces: Global and Local Actors, networks and embeddedness. London and Ney York, NY: Routledge, 247-263.

Dorocki, S., Kroczak, R., Bryndal, T. (2019). Zmiany pokrycia terenu w polskich Karpatach na przełomie XX i XXI w. a poziom rozwoju lokalnego. Przedsiębiorczość - Edukacja, 15(1), 214-229.

Flanigan S., Blackstock K., Hunter C. (2015). Generating public and private benefits through understanding what drives different types of agritourism. Journal of Rural Studies, 41(1), 394-405.

Fleischer, A., Tchetchik, A. (2005). Does rural tourism benefit from agriculture? Tourism Management, 26(4), 493-501. 
Gralak, K., Kacprzak, M. (2018). Agroturystyka w rozwoju obszarów wiejskich w Polsce - stan, problemy $i$ perspektywy. Pozyskano z: https://cejsh.icm.edu.pl/cejsh/element/bwmeta1.../012Agroturystyka_w_rozwoju\%20(3).pdf

Karampela, S., Kizos, T., Spilanis, I. (2016). Evaluating the impact of agritourism on local development in small Island. Island Studies Journal, 11(1), 161-176.

Komorowska, K.A. (2003). Turystyka a społeczność lokalna - przykład tatrzański. Studia Regionalne i Lokalne, 3(13), 79-87.

Koutsouris, A., Gidarakou, I., Grava, F., Michailidis, A. (2014). The phantom of (agri) tourism and agriculture symbiosis? A Greek case study. Tourism Management Perspectives, 12, 94-103.

Kizos, T. (2010). Multifunctionality of farm households in Greece. Norsk Geografisk Tidsskrift_Norwegian Journal of Geography, 64(2), 105-116.

Klima, K. (2015). The impact of agritourism on the land-use pattern of small farms operating in the Beskidy Mountains. Problems of Small Agricultural Holdings, 3, 27-33.

Krysa, A., Basaj, M. (2010). Agroturystyka jako kierunek rozwoju gminy Gdów w opinii jej mieszkańców. Problemy Ekologii Krajobrazu, 27, 225-230.

Kurek, W. (2008). Tourism in Polish Carpathians in the political transition time. Conditions of the Foreign Tourist Development in Central and Eastern Europe. Tourism in Geographical Environment, 10, 295-302.

Marin, D. (2015). Study on the economic impact of tourism and of agrotourism on local communities. Research Journal of Agricultural Science, 47(4), 160-163.

McGehee, N.G., Kim, K. (2004). Motivation for agri-tourism entrepreneurship. Journal of Travel Research, 43(2), 161-170.

Musiał, W., Sroka, W., Wojewodzic T. (2010). Sytuacja ekonomiczna gospodarstw z terenów górskich i podgórskich. Warszawa: Instytut Ekonomiki Rolnictwa i Gospodarki Żywnościowej, Państwowy Instytut Badawczy.

Mysiak, K. (2000). Agroturystyka - szansa na nowe miejsca pracy na wsi. Problemy Turystyki $i$ Hotelarstwa, 47-50.

Pałka-Łebek, E. (2017). An exploration of the role of agritourism in revitalizing rural areas - the case study of Southeast Poland. Zeszyty Naukowe. Turystyka i Rekreacja, 2(20), 141-149.

Parysek, J.J. (1997). Podstawy gospodarki lokalnej. Poznań: Uniwersytet Adama Mickiewicza.

Petrović, M.D., Blešić, I., Ivolga, A., Vujko, A. (2016). Agritourism Impact Toward Locals' Attitudes An Evidence from Vojvodina Province (Serbia). Journal of the Geographical Institute, 66(1), 105123.

Phillip, S., Hunter, C., Blackstock, K. (2010). A typology for defining agritourism. Tourism Management, $31,754-758$.

Płazińska, K. (2016). Obszary przyrodniczo cenne czynnikiem wpływającym na rozmieszczenie gospodarstw agroturystycznych w Polsce. W: S. Graja-Zwolińska, A. Spychała, K. Kasprzak (red.) Turystyka wiejska. Zagadnienia przyrodnicze i kulturowe. Poznań: Wieś Jutra Sp. z o.o., 16-22.

PROW 2014-2020. Program Rozwoju Obszarów Wiejskich 2014-2020. (2014). Warszawa: Ministerstwo Rolnictwa i Rozwoju Wsi. Pozyskano z: https://www.gov.pl/web/rolnictwo/-program-rozwoju-obszarow-wiejskich-2014-2020-prow-2014-2020

Przezbórska-Skobiej, L., Sobotka, S. (2016). Propozycja delimitacji regionów agroturystycznych w Polsce. Wieś i Rolnictwo, 2(171), 173-197.

Rogerson, C.M., Rogerson, JM. (2014). Agritourism and local economic development in South Africa. Bulletin of Geography, Socio-Economic Series, 26, 93-106.

Roman, M., Niedziółka, A. (2017). Agroturystyka jako forma przedsiębiorczości na obszarach wiejskich. Warszawa: SGGW.

Rowe, J.E. (ed.). (2009). Theories of local development economic. London: Routledge.

Sektorowy Program Operacyjny „Restrukturyzacja i modernizacja sektora żywnościowego oraz rozwój obszarów wiejskich 2004-2006". (2019, 11 kwietnia). Pozyskano z: https://www.arimr.gov.pl/programy-2002-2013/spo-rolnictwo-2004-2006.html 
Sikora, J. (2014). Turystyka wiejska, w tym agroturystyka, w kontekście perspektyw rozwoju wsi i rolnictwa w Polsce: analiza wyników badań empirycznych. Ekonomiczne Problemy Turystyki, 3(27), 113-126.

Stanovčić, T., Peković, S., Vukčević, J., Perović D. (2018). Going entrepreneurial: Agri-tourism and rural development in Northern Montenegro. Business Systems Research, 9(1), 107-117.

Sznajder, M., Przezbórska, L. (2006). Agroturystyka. Warszawa: Polskie Wydawnictwo Ekonomiczne.

Tew, Ch., Barbieri, C. (2012). The perceived benefits of agritourism: The provider's perspective. Tourism Management, 33(1), 215-224.

Tracz, M., Bajgier-Kowalska, M., Uliszak, R. (2018). Rozwój agroturystyki w południowo-wschodniej Polsce - ujęcie modelowe. Przedsiębiorczość - Edukacja, 14, 229-334.

Tracz, M., Bajgier-Kowalska, M., Uliszak, R. (2017). The development of agritourism in the Podkarpackie Voivodeship in the light of international and national conditions. Przedsiębiorczość - Edukacja, 13, 224-261.

Wang, Y., Pfister, R.E. (2008). Residents' Atitudes toward Tourism and Perceived Personal Benefits in a Rural Community. Journal of Travel Research, 3(1), 1-10.

Wojciechowska, J. (2009). Procesy i uwarunkowania rozwoju agroturystyki w Polsce. Łódź: Wydawnictwo Uniwersytetu Łódzkiego.

Woźniak, M., Kuźniar, W. (2000). Znaczenie agroturystyki w ożywieniu gospodarczym obszarów górskich (na przykładzie Podkarpacia). W: Turystyka wiejska w perspektywie europejskiej. Materiały konferencyjne, KCDRRiOW Oddział w Krakowie, Kraków.

Zawadka, J. (2010). Ewolucja działalności agroturystycznej w Polsce i typologia wiejskich gospodarstw turystycznych. Acta Scientiarum Polonorum, Oeconomia, 9(4), 627-638.

Zioło, Z. (2016). Przedsiębiorczość w rozwoju układów lokalnych. Przedsiębiorczość - Edukacja, 12, 6-17.

Mariola Tracz, doktor, geograf, dydaktyk geografii, członkini Polskiego Towarzystwa Geograficznego. Zainteresowania naukowe skupiają się wokół dydaktyki geografii (programy nauczania, edukacja geograficzna a kształtowanie kompetencji, historia geografii i jej dydaktyki), geografii społeczno-gospodarczej (polityka edukacyjna państwa, edukacja a rozwój gospodarczy) oraz wybranych problemów turystyki (agroturystyka, turystyka miejska, turystyka kulturowa).

Mariola Tracz, $\mathrm{PhD}$, geographer, didactic of geography, member of the Polish Geographical Society. Interested in: geography education (geography curriculum, development of geography competency, geography on examination, history of geography education in Poland), socio-economic geography and tourism (agritourism, cultural tourism).

ORCID: 0000-0002-0019-8665

\section{Adres/Address:}

Polskie Towarzystwo Geograficzne, Oddział w Krakowie

ul. Podchorążych 2

30-084 Kraków, Polska

e-mail: mtracz-62@o2.pl

Małgorzata Bajgier-Kowalska, doktor, adiunkt w Katedrze Turystyki Międzynarodowej i Geografii Społecznej, na Wydziale Prawa, Administracji i Stosunków Międzynarodowych Krakowskiej Akademii im. Andrzeja Frycza Modrzewskiego. Zainteresowania naukowo-badawcze i tematyka publikacji koncentrują się wokół problemów geomorfologicznych oraz zagadnień z zakresu geografii regionalnej. Badania autorki koncentrują się również na problematyce rozwoju turystyki i rekreacji, głównie na zagadnieniach uwarunkowania rozwoju i funkcjonowania regionów turystycznych na świecie, analizie przestrzennego zróżnicowania zagospodarowania turystycznego oraz wielkości ruchu turystycznego. 
Małgorzata Bajgier-Kowalska, PhD, assistant professor, Andrzej Frycz Modrzewski Krakow University, Faculty of Law, Administration and International Relations, Department of International Tourism and Social Geography. Research issues, as well as publication themes concentrate on geomorphology and issues concerning regional geography. Author's research concentrates also on the problem of tourism and recreation growth, especially on the question of development conditions and functioning of tourist regions in the world, including the analyses of spatial differentiation of tourist infrastructure and the size of tourism itself.

ORCID: 0000-0002-2942-2181

\section{Adres/Address:}

Krakowska Akademia im. A.F. Modrzewskiego

ul. G. Herlinga-Grudzińskiego 1

30-705 Kraków, Polska

e-mail: malbajkow@interia.pl 